\title{
PENGARUH BUDAYA ORGANISASI DAN KOMUNIKASI TERHADAP KINERJA KARYAWAN PADA PT BANK CENTRAL ASIA, TBK. CABANG PEMATANGSIANTAR
}

\author{
Oleh: \\ Kevin Indajang \\ S-1 Manajemen \\ Darwin Lie, Efendi, Andy Wijaya
}

Abstraksi

Adapun rumusan masalah penelitian ini adalah bagaimana pengaruh budaya organisasi dan komunikasi terhadap kinerja karyawan pada PT Bank Central Asia, Tbk. Cabang Pematangsiantar. Metode yang digunakan dalam penulisan ini adalah penelitian kepustakaan dan penelitian lapangan. Populasinya adalah seluruh karyawan tetap PT Bank Central Asia, Tbk. Cabang Pematangsiantar yang berjumlah 41 orang. Data yang digunakan adalah data kualitatif dan data kuantitatif, dan teknik pengumpulan data yang digunakan adalah metode kuesioner, metode wawancara dan metode dokumentasi. Kemudian teknik analisis data menggunakan metode deskriptif kualitatif dan metode deskriptif kuantitatif.

Hasil penelitian: 1. Budaya organisasi yang dilaksanakan oleh karyawan dan komunikasi serta kinerja yang dihasilkan sudah baik. 2. Hasil regresi berganda diperoleh persamaan regresi sebagai berikut: $\hat{Y}=10,054+0,357 \mathrm{X}_{1}+0,514 \mathrm{X}_{2}$, artinya terdapat pengaruh yang positif antara budaya organisasi dan komunikasi terhadap kinerja karyawan PT Bank Central Asia, Tbk. Cabang Pematangsiantar. 3 . Analisis koefisien yaitu $r=0,728$ yang artinya terdapat hubungan yang kuat dan positif antara budaya organisasi dan komunikasi dengan kinerja karyawan PT Bank Central Asia, Tbk. Cabang Pematangsiantar. 4. Nilai koefisien determinasi (KD) 0,530, artinya tinggi rendahnya kinerja karyawan dapat dijelaskan sebesar $53 \%$ oleh budaya organisasi dan komunikasi, selebihnya $47 \%$ dijelaskan oleh faktor-faktor lain seperti komitmen, kepribadian, motivasi, pemberian insentif, dan faktor-faktor lain yang tidak dijelaskan dalam penelitian ini. 5. Uji hipotesis $\mathrm{H}_{0}$ ditolak, artinya budaya organisasi dan komunikasi berpengaruh positif dan signifikan terhadap kinerja karyawan baik secara simultan maupun parsial.

Kata kunci: Budaya Organisasi, Komunikasi, dan Kinerja Karyawan.

\section{Abstraction}

The formulation of this research problem is how the influence of organizational culture and communication on employee perfomance at PT Bank Central Asia, Tbk. Cabang Pematangsiantar. The method used in this paper is literature research and field research. The population is all employees of PT Bank Central Asia, Tbk. Cabang Pematangsiantar which amounted to 41 people. The data used are qualitative data and quantitative data, and data collection techniques used are questionnaire method, interview method and documentation method. Then the technique of data analysis using qualitative descriptive method and quantitative descriptive method.

The result of this research: 1. Organizational culture implemented by employees and communication and the resulting performance is good. 2. The results of multiple regression analysis obtained the following regression equation: $\hat{Y}=10,054+0,357 X_{1}+0,514 X_{2}$, meaning that there are positive influence between organizational culture and communication on employees performance of $P T$ Bank Central Asia, Tbk. Cabang Pematangsiantar. 3. Analysis coefficient is $r=0,728$, which means there is a moderately high and positive correlation between organizational culture and communication with the performance of employees of PT Bank Central Asia, Tbk. Cabang Pematangsiantar. 4. The value of the coefficient of determination (KD) 0,530, meaning that the level of employee performance can be explained by $53 \%$ by organizational culture and communication, the other $47 \%$ explained by other factors like commitment, personality, motivation, and other factors not described in this study. 5 . Hypothesis $H_{0}$ is rejected, meaning that organizational culture and communication have positive and significant effect to employee's performance either simultaneously or partially.

\section{Keywords: Organizational Culture, Communication, and Employee Performance.}

\section{A. PENDAHULUAN}

\section{Latar Belakang Masalah}

PT Bank Central Asia, Tbk. Cabang Pematangsiantar merupakan salah satu bank swasta terbesar di Indonesia, khususnya di Pematangsiantar yang selalu memandang sumber daya manusia sebagai asset utama yang harus dan wajib untuk dikembangkan. PT Bank Central Asia, Tbk. Cabang Pematangsiantar melalui manajemen sumber daya manusianya selalu berusaha meningkatkan kualitas sumber daya manusia 
karyawannya guna meningkatkan kinerjanya dalam memberikan kualitas pelayanan yang memuaskan bagi nasabah.

Fenomena kinerja karyawan PT Bank Central Asia, Tbk. Cabang Pematangsiantar, yaitu kurangnya kemampuan komunikas karyawan dalam hal menyampaikan informas serta berbahasa asing dan adanya beberapa karyawan yang sulit menerima kritik dan saran dari orang lain serta kurang memiliki motivasi dan semangat dalam melaksanakan pekerjaannya sehingga kinerja yang dihasilkan kurang optimal. Oleh sebab itu perlu dilakukan peningkatan kerja karyawan. Terdapat banyak faktor yang mempengaruhi kinerja karyawan, diantaranya adalah budaya organisasi dan komunikasi.

Dimensi budaya organisasi pada PT Bank Central Asia, Tbk. Cabang Pematangsiantar dari budaya kejujuran, budaya ketekunan, budaya kreativitas, budaya kedisiplinan dan budaya IPTEK. Dilihat dari dimensi budaya kedisiplinan masih terdapat karyawan yang tidak memohon ijin apabila terdapat keperluan tertentu.

Faktor lain yang mempengaruhi kinerja karyawan pada PT Bank Central Asia, Tbk. Cabang Pematangsiantar adalah komunikasi. Komunikasi yang terjadi di PT Bank Central Asia, Tbk. Cabang Pematangsiantar dapat berbentuk komunikasi nonverbal dan komunikasi verbal. Komunikasi nonverbal ditunjukkan dengan gerakan tubuh, gerak mata, tekanan suara, postur tubuh, sikap, dan sebagainya. Contohnya apabila ada karyawan yang kesulitan menggunakan mesin fotocopy maka karyawan lain akan membantu dan mengajari karyawan yang kesulitan menggunakan mesin tersebut.

Komunikasi verbal ditunjukkan dengan penyampaian pesan secara lisan atau tertulis. Contohnya, terdapat pesan-pesan khusus yang dilengkapi dengan simbol tertentu yang berguna sebagai arahan dan petunjuk bagi setiap karyawan yang terdapat di setiap ruang kerja, meja kerja, atau langsung berkomunikasi secara lisan. Dilihat dari sisi komunikasi nonverbal terdapat karyawan yang kurang memahami pesan ataupun informasi yang disampaikan melalui gerak mata sehingga kadang kala terjadi kesalahpahaman antar karyawan yang berkomunikasi.

Budaya organisasi yang baik serta komunikasi yang efektif akan meningkatkan kinerja karyawan.

\section{Rumusan Masalah}

a. Bagaimana gambaran budaya organisasi, komunikasi dan kinerja karyawan pada PT Bank Central Asia, Tbk. Cabang Pematangsiantar.

b. Bagaimana pengaruh budaya organisasi dan komunikasi terhadap kinerja karyawan pada
PT Bank Central Asia, Tbk. Cabang Pematangsiantar baik secara simultan maupun parsial.

\section{Tujuan Penelitian}

a. Untuk mengetahui gambaran budaya organisasi, komunikasi dan kinerja karyawan pada PT Bank Central Asia, Tbk. Cabang Pematangsiantar.

b. Untuk mengetahui pengaruh budaya organisasi dan komunikasi terhadap kinerja karyawan pada PT Bank Central Asia, Tbk. Cabang Pematangsiantar baik secara simultan maupun parsial.

\section{Metode Penelitian}

Objek penelitian adalah PT Bank Central Asia, Tbk. Cabang Pematangsiantar yang terletak di Jalan Merdeka No. 39 Pematangsiantar, Sumatera Utara. Populasi adalah seluruh karyawan tetap PT Bank Central Asia, Tbk. Cabang Pematangsiantar yang berjumlah 41 orang. Pengambilan sampel digunakan dengan metode sampel jenuh yang berarti semua anggota populasi digunakan sebagai sampel.

Desain penelitian adalah Penelitian Kepustakaan (Library Research) dan Penelitian Lapangan (Field Research). Teknik pengumpulan data berupa Kuesioner, Wawancara, Dokumentasi dan Observasi. Jenis data yang adalah jenis data kualitatif dan data kuantitatif. Hasil data yang diperoleh dari lapangan akan dianalisis secara deskriptif baik bersifat kualitatif dan kuantitatif.

\section{B. LANDASAN TEORI}

\section{Manajemen Sumber Daya Manusia}

Menurut Mondy (2008:4), manajemen sumber daya manusia adalah pemanfaatan sejumlah individu untuk mencapai tujuan-tujuan organisasi. Menurut Mathis dan John (2006:3), manajemen sumber daya manusia adalah rancangan sistem-sistem formal dalam sebuah organisasi untuk memastikan penggunaan bakat manusia secara efektif dan efisien guna mencapai tujuan-tujuan organisasional. Sedangkan menurut Dessler (2003:5), manajemen sumber daya manusia adalah proses memperoleh, melatih, menilai, dan memberikan kompensasi kepada karyawan, memerhatikan hubungan kerja mereka, kesehatan, keamanan, dan masalah keadilan. Melalui definisi-definisi di atas, maka manajemen sumber daya manusia dapat diartikan sebagai pendayagunaan bakat manusia secara efektif dan efisien melalui proses memperoleh, melatih, menilai, dan memberikan kompensasi kepada karyawan, memerhatikan hubungan kerja mereka, kesehatan, keamanan, dan masalah keadilan guna mencapai tujuan organisasi.

\section{Budaya Organisasi}


Menurut Robbins (2006:721), budaya organisasi adalah sistem makna bersama yang dianut oleh anggota-anggota yang membedakan organisasi itu dari organisasiorganisasi lain. Menurut Sutrisno (2010:2), budaya organisasi adalah perangkat sistem nilai-nilai (values), keyakinan-keyakinan (beliefs), asumsi-asumsi (assumptions), atau norma-norma yang telah lama berlaku, disepakati dan diikuti oleh para anggota suatu organisasi sebagai pedoman perilaku dan pemecahan masalah-masalah organisasinya.

Sedangkan menurut Kreitner dan Angelo (2014:62), budaya organisasi adalah perangkat asumsi yang dibagi dan diterima secara implisit begitu saja serta dipegang oleh satu kelompok yang menentukan bagaimana hal itu dirasakan, dipikirkan, dan bereaksi terhadap lingkungan yang beragam. Dari definisi di atas, dapat disimpulkan bahwa budaya organisasi adalah pedoman dasar bagi anggota organisasi dalam berperilaku dan memecahkan masalah organisasinya sesuai dengan nilai, keyakinan, asumsi dan norma yang telah disepakati sekaligus sebagai identitas sebuah organisasi yang membedakannya dengan organisasi lain.

Menurut Robbins (2006:301), dimensi budaya organisasi yang digunakan adalah dimensi kejujuran, ketekunan, kreativitas, kedisiplinan, dan IPTEK.

\section{Komunikas}

Menurut Purwanto (2006:2), komunikasi adalah suatu proses pertukaran informasi antar individu melalui suatu sistem yang biasa (lazim), baik dengan simbol-simbol, sinyalsinyal, maupun perilaku atau tindakan. Menurut Boone dan David (2002:365), komunikasi dapat didefenisikan sebagai pertukaran informasi yang berharga melalui pesan-pesan.

Sedangkan menurut Bangun (2012:360) komunikasi merupakan proses menyampaikan informasi dari pengirim kepada penerima pesan secara efektif. Dengan demikian dapat disimpulkan bahwa komunikasi merupakan proses pertukaran informasi yang berharga antar individu melalui simbol-simbol, sinyalsinyal, perilaku ataupun tindakan yang dilakukan secara efektif.

Menurut Dewi (2007:7), bentuk dasar komunikasi terbagi menjadi dua yaitu komunikasi nonverbal dan komunikasi verbal.

\section{Kinerja Karyawan}

Menurut Bangun (2012:231), kinerja (performance) adalah hasil yang dicapai seseorang berdasarkan persyaratanpersyaratan pekerjaan (job requirement). Suatu pekerjaan mempunyai persyaratan tertentu untuk dapat dilakukan dalam mencapai tujuan yang disebut juga sebagai standar pekerjaan (job standard). Menurut Mathis dan John (2006:378), kinerja (performance) pada dasarnya adalah apa yang dilakukan atau tidak dilakukan oleh karyawan. Sedangkan menurut Zainal, dkk (2015:447), kinerja merupakan suatu istilah secara umum yang digunakan untuk sebagian atau seluruh tindakan atau aktivitas dari suatu organisasi pada suatu periode dengan referensi pada sejumlah standar seperti biaya-biaya masa lalu atau yang diproyeksikan, dengan dasar efisiensi, pertanggungjawaban atau akuntabilitas manajemen dan semacamnya. Berdasarkan pendapat para ahli di atas dapat disimpulkan bahwa kinerja merupakan hasil kerja yang dicapai seorang karyawan dalam suatu organisasi dalam melaksanakan tugas yang dibebankan sesuai dengan tanggung jawab yang diberikan.

Menurut form penilaian karyawan BCA tahun 2005-2016, maka dapat disimpulkan penilaian kinerja karyawan di BCA secara umum mencakup kemampuan komunikasi, kerjasama, kemauan untuk berkembang, pengetahuan produk dan kemandirian.

\section{PEMBAHASAN}

\section{Analisa}

\section{a. Deskriptif Kualitatif}

Analisis deskriptif dimaksudkan untuk mendapatkan gambaran atau deskripsi mengenai tanggapan dari karyawan mengenai Pengaruh Budaya Organisasi dan Komunikasi terhadap Kinerja Karyawan pada PT Bank Central Asia, Tbk. Cabang Pematangsiantar. Setelah pengujian data, maka langkah selanjutnya peneliti melakukan pengkajian analisis kualitatif sebagai gambaran fenomena dari variabel penelitian pada saat sekarang ini. Adapun penetapan kriteria nilai rata-rata jawaban dari responden tersebut dimasukkan ke dalam kelas-kelas interval dimana penentuan intervalnya memakai rumus sebagai berikut:

Interval Kelas $=\underline{\text { Nilai Tertinggi }- \text { Nilai Terendah }}$

$$
\begin{aligned}
& =\frac{5-1}{5} \quad \text { Jumlah Kelas } \\
& =\frac{4}{5}
\end{aligned}
$$$$
=0,8
$$

Dari rumus diatas dapat diperoleh interval kelas 0,8 sehingga berlaku ketentuan kategori dengan hasil berikut:

Tabel 1

Nilai Interval dan Kategori Jawaban

\begin{tabular}{|c|c|c|c|}
\hline \multirow[b]{2}{*}{ Niai hterval } & \multicolumn{3}{|c|}{ Kategori } \\
\hline & $\begin{array}{c}\text { Budaya } \\
\text { Omganisasi }\end{array}$ & Komunikasi & Kinerja Karyawan \\
\hline $10-1,30$ & Sangal Tdat $\theta$ s!ik & Sarngt Tivel Bak & Sargal Fioek Eak \\
\hline $181-2,20$ & Titek Baik & Tdar. B:ik & Tidak Baic \\
\hline $261-3,+0$ & Cukus Bak & Cusop Eaik. & Cltup Bas \\
\hline $341-4,20$ & Bejik & Eak: & Ealk \\
\hline $421-5,20$ & Sangal Dak. & Sencat:Baik & Sangat B:k \\
\hline
\end{tabular}
Responden 
Sumber: hasil pengolahan data (2017)

1) Gambaran Budaya Organisasi pada PT Bank Central Asia, Tbk. Cabang Pematangsiantar

Budaya organisasi merupakan pedoman dasar bagi anggota organisasi dalam berperilaku dan memecahkan masalah organisasinya sesuai dengan nilai, keyakinan, asumsi dan norma yang telah disepakati sekaligus sebagai identitas sebuah organisasi yang membedakannya dengan organisasi lain.

Budaya organisasi yang diterapkan oleh PT Bank Central Asia, Tbk. Cabang Pematangsiantar antara lain budaya kejujuran, budaya ketekunan, budaya kreativitas, budaya kedisiplinan, dan budaya IPTEK. Budaya kejujuran diterapkan melalui Code of Conduct, yaitu peraturan dan tata tertib dasar yang wajib dipatuhi oleh segenap karyawan termasuk jajaran direksi dan dewan komisaris. Budaya ketekunan mewajibkan semua karyawan PT Bank Central Asia, Tbk. Cabang Pematangsiantar tekun dalam melaksanakan tugas yang dibebankan kepadanya dengan berpedoman pada Tata Nilai BCA. Budaya kreativitas diterapkan melalui BCA Innovation yang mendorong karyawan PT Bank Central Asia, Tbk. Cabang Pematangsiantar untuk berpikir kreatif dan inovatif.

Budaya kedisiplinan diterapkan melalui Program Kaizen atau yang lebih dikenal dengan sebutan Program 5R (Ringkas, Rapi, Resik, Rawat, Rajin). Melalui program 5R ini, karyawan PT Bank Central Asia, Tbk. Cabang Pematangsiantar mempraktekkan disiplin diri. Budaya IPTEK digunakan untuk mendorong karyawan PT Bank Central Asia, Tbk. Cabang Pematangsiantar selalu mengikuti era dari perkembangan teknologi komputerisasi dan memanfaatkannya untuk menyelesaikan tugas.

Untuk keseluruhan dapat dilihat bahwa untuk total jawaban responden mengenai budaya organisasi dari segi budaya kejujuran, budaya ketekunan, budaya kreativitas, budaya kedisiplinan dan budaya IPTEK mendapat nilai rata-rata sebesar 3,82 dengan kriteria jawaban baik. Nilai rata-rata jawaban responden tertinggi ada pada indikator penguasaan IPTEK oleh karyawan bernilai 4,05 dengan kriteria baik. Sedangkan nilai rata-rata terendah sebesar 3,29 dengan kriteria jawaban cukup baik dengan indikator permohonan ijin karyawan untuk keperluan tertentu.

\section{2) Gambaran Komunikasi pada PT Bank Central Asia, Tbk. Cabang Pematangsiantar}

Komunikasi merupakan proses pertukaran informasi yang berharga antar individu melalui simbol-simbol, sinyal-sinyal, perilaku ataupun tindakan yang dilakukan secara efektif. Komunikasi dalam perusahaan memiliki fungsi sebagai informasi, sebagai kendali dan sebagai motivasi yang dimaksudkan untuk meningkatkan kinerja kerja karyawan agar dapat mencapai visi, misi dan tujuan perusahaan.

Sedangkan komunikasi pada PT Bank Central Asia, Tbk. Cabang Pematangsiantar setelah dilakukan observasi masih terdapat aspek yang masih kurang sehingga perlu adanya perbaikan dalam komunikasi PT Bank Central Asia, Tbk. Cabang Pematangsiantar.

Untuk keseluruhan dapat dilihat bahwa untuk total jawaban responden mengenai komunikasi dari segi komunikasi nonverbal dan komunikasi verbal mendapat nilai rata-rata sebesar 3,82 dengan kriteria jawaban baik. Kemudian nilai rata-rata tertinggi sebesar 4,05 dengan kriteria jawaban baik pada dimensi komunikasi nonverbal dengan indikator gerak tubuh karyawan dalam menyampaikan informasi. Sedangkan nilai rata-rata terendah sebesar 3,39 dengan kriteria cukup baik pada dimensi komunikasi nonverbal dengan indikator gerak mata karyawan dalam menyampaikan informasi.

\section{3) Gambaran Kinerja Karyawan pada PT Bank Central Asia, Tbk. Cabang Pematangsiantar}

Kinerja dalam suatu organisasi atau perusahaan merupakan hasil dari tujuan suatu organisasi atau perusahaan. Hasil kinerja karyawan sangat penting diketahui untuk mengevaluasi kinerja karyawan dari organisasi atau perusahaan apakah telah sesuai dengan visi, misi dan tujuan organisasi atau perusahaan tersebut.

Kinerja PT Bank Central Asia, Tbk. Cabang Pematangsiantar dipengaruhi oleh beberapa faktor yaitu kemampuan komunikasi, kerjasama, kemauan untuk berkembang, pengetahuan produk, kemandirian. Dalam mencapai visi, misi dan tujuan perusahaan dibutuhkan penilaian kinerja karyawan agar menjadi tolak ukur bagi perusahaan untuk mengetahui bagaimana kinerja dari karyawannya. Penilaian kinerja karyawan ini berguna sebagai bahan pertimbangan bagi bagian manajemen sumber daya manusia untuk mengambil keputusan berdasarkan hasil kinerja karyawannya.

Untuk keseluruhan dapat dilihat bahwa total jawaban responden mengenai kinerja karyawan baik dari segi kemampuan komunikasi, kerjasama, kemauan untuk berkembang, pengetahuan produk, kemandirian mendapat nilai rata-rata 3,75 dengan kriteria jawaban baik. Kemudian nilai rata tertinggi sebesar 4,20 dengan kriteria jawaban baik pada dimensi kemampuan komunikasi dengan indikator kemampuan karyawan dalam berbahasa yang sopan. Sedangkan nilai rata- 
rata terendah sebesar 3,02 dengan kriteria jawaban cukup baik pada dimensi kemampuan komunikasi dengan indikator kemampuan karyawan dalam berbahasa asing.

\section{b. Deskriptif Kuantitatif}

\section{1) Regresi Linear Berganda}

Penelitian ini memiliki tujuan untuk menganalisis pengaruh budaya organisasi dan komunikasi terhadap kinerja karyawan. Analisis data dalam penelitian ini menggunakan analisis regresi linier berganda. Analisis regresi linier berganda digunakan untuk mengetahui pengaruh variabel bebas $(X)$ dan variabel terikat $(\mathrm{Y})$, dimana $\mathrm{X}$ adalah budaya organisasi, komunikasi dan $\mathrm{Y}$ adalah kinerja karyawan. Maka dilakukan perhitungan menggunakan program aplikasi SPSS versi 21 dengan hasil hitung regresi sebagai berikut:

\section{Tabel 2}

Hasil Regresi Linier Berganda Coefficients $^{a}$

\begin{tabular}{|c|c|c|c|}
\hline \multirow{2}{*}{ Wodel } & \multicolumn{2}{|c|}{ Unstumusmizzd Coefficients } & 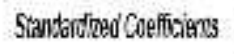 \\
\hline & B & Sora Eror & Beta \\
\hline Carow & 10,654 & 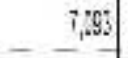 & \\
\hline Bidola Otacicias & .157 &, 148 & A15 \\
\hline Kumunbaj & .514 & . 44 & 35 \\
\hline
\end{tabular}

a. Dependent Variabel: Kinerja Karyawan

Sumber: hasil pengolahan data instrumen dengan SPSS Ver.21 (2017)

Berdasarkan hasil pengolahan tabel $2 \mathrm{di}$ atas, dapat diperoleh persamaan regresi sebagai berikut: $\hat{Y}=10,054+0,357 X_{1}+$ $0,514 \mathrm{X}_{2}$, artinya terdapat pengaruh positif antara budaya organisasi dan komunikasi terhadap kinerja karyawan pada PT Bank Central Asia, Tbk. Cabang Pematangsiantar.

\section{2) Korelasi dan Koefisien Determinasi}

Hasil korelasi dan koefisien determinasi dapat dilihat pada tabel berikut:

Tabel 3

Hasil Korelasi dan Determinasi Model Summary ${ }^{b}$

\begin{tabular}{|c|c|c|c|c|}
\hline Notal & $R$ & R Syare & Afustida R SquJe & $\begin{array}{l}\text { Sto. Emor of the } \\
\text { Estomate }\end{array}$ \\
\hline 1 &, $722^{3}$ & 500 & 515 & 3840 \\
\hline
\end{tabular}

a. Predictors: (Constant), Budaya Organisasi, Komunikasi

b. Dependent Variabel: Kinerja Karyawan
Sumber: hasil pengolahan data instrumen dengan SPSS Ver.21 (2017)

Berdasarkan tabel 3 diperoleh nilai $r=$ 0,728 yang artinya terdapat hubungan yang kuat dan positif antara budaya organisasi dan komunikasi dengan kinerja karyawan PT Bank Central Asia, Tbk. Cabang Pematangsiantar. Kemudian diperoleh koefisien determinasi $\mathrm{R}=$ 0,530 , artinya tinggi rendahnya kinerja karyawan dapat dijelaskan sebesar $53 \%$ oleh budaya organisasi dan komunikasi, selebihnya $47 \%$ dijelaskan oleh faktor lain seperti komitmen, kepribadian, kepuasan kerja, motivasi, pemberian insentif, kompensasi, gaya kepemimpinan dan faktor-faktor lain yang tidak dibahas dalam penelitian ini.

\section{3) Uji Hipotesis}

\section{a) Uji Simultan (Uji F)}

Pengujian ini dilakukan secara simultan, yaitu dilakukan untuk menentukan diterima atau ditolaknya hipotesis. Pengujian hipotesis dilakukan untuk mengetahui apakah variabel budaya organisasi dan komunikasi yang diuji berpengaruh terhadap kinerja karyawan. Jika $\mathrm{F}_{\text {hitung }}>\mathrm{F}_{\text {tabel }}$ atau signifikansi $\leq 0,05$, maka $\mathrm{H}_{0}$ ditolak.

Untuk menghasilkan suatu kesimpulan yang valid, maka harus dilakukan uji hipotesis dengan menggunakan program SPSS versi 21.

$$
\text { Tabel } 4
$$

Hasil Uji Simultan (Uji F) ANOVA $^{a}$

\begin{tabular}{|c|c|c|c|c|c|c|}
\hline & Natei & $\begin{array}{l}\text { Som of } \\
\text { Soures }\end{array}$ & of & Mexn Square & $F$ & Siy. \\
\hline \multirow{3}{*}{1} & Pegresion & 64,720 & 2 & $315: 93$ & 21,333 & 0 \\
\hline & Bosidıa & 3223 & 38 & 14.45 & & \\
\hline & โรฌ] & $1: 1,04$ & 40 & & & \\
\hline
\end{tabular}

a. Dependent Variabel: Kinerja Karyawan

b. Predictors: (Constant), Budaya Organisasi, Komunikasi

Sumber: hasil pengolahan data instrumen dengan SPSS Ver.21 (2017)

Berdasarkan tabel 4 di atas, diperoleh nilai $F_{\text {hitung }}$ sebesar 21,393 $>F_{\text {tabel }}(5 \%, 2 \mathrm{VS}$ 38) sebesar 3,24 atau dengan taraf signifikansinya $0,000<\alpha 0,05$ maka $\mathrm{H}_{0}$ ditolak, artinya budaya organisasi dan komunikasi berpengaruh positif dan signifikan terhadap kinerja karyawan PT Bank Central Asia, Tbk. Cabang Pematangsiantar.

\section{b) Uji Parsial (Uji t)}

Pengujian ini dilakukan secara parsial yang dilakukan untuk menentukan diterima atau ditolaknya hipotesis. Pengujian hipotesis dilakukan untuk mengetahui apakah variabel budaya organisasi dan komunikasi yang diuji 
berpengaruh terhadap kinerja karyawan. Jika $t_{\text {hitung }}>t_{\text {tabel }}$ atau signifikansi $\leq 0,05$, maka $\mathrm{H}_{0}$ ditolak.

Tabel 5

Hasil Uji Parsial (Uji t) Coefficients $^{a}$

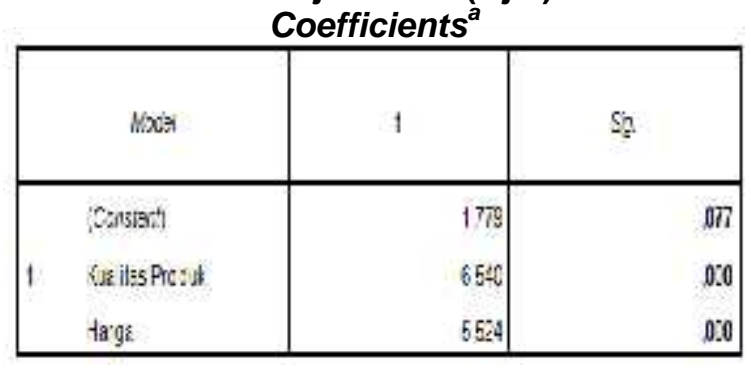

a. Dependent Variabel: Kinerja Karyawan

Sumber: hasil pengolahan data instrumen dengan SPSS Ver.21 (2017)

Berdasarkan tabel 5 diperoleh nilai $t_{\text {hitung }}$ pada variabel budaya organisasi sebesar 2,418 $>\mathrm{t}_{\text {tabel }}$ dengan $\mathrm{df}=\mathrm{n}-\mathrm{k}-1 \quad(41-2-1=38)$ sebesar 2,024 atau dengan taraf signifikan $0,020<\alpha$ 0,05 , maka $\mathrm{H}_{0}$ ditolak, artinya budaya organisasi berpengaruh positif dan signifikan terhadap kinerja karyawan pada PT Bank Central Asia, Tbk. Cabang Pematangsiantar. Nilai variabel komunikasi sebesar 2,084 $>t_{\text {tabel }}$ dengan df $=\mathrm{n}-\mathrm{k}-1 \quad(41-2-1=38)$ sebesar 2,024 atau dengan taraf signifikansi $0,044<\alpha 0,05$ maka $\mathrm{H}_{0}$ ditolak, artinya komunikasi berpengaruh positif dan signifikan terhadap kinerja karyawan pada PT Bank Central Asia, Tbk. Cabang Pematangsiantar.

\section{Evaluasi}

a. Budaya Organisasi pada PT Bank Central Asia, Tbk. Cabang Pematangsiantar

Pada dimensi budaya kejujuran, dengan indikator sikap karyawan berani menolak melakukan tindakan fraud memperoleh nilai rata-rata 3,78 dengan kriteria jawaban baik. Sikap karyawan berani menolak melakukan tindakan fraud dapat ditingkatkan dengan cara memberikan sosialiasi tentang kerugian dan dampak fraud. Pada dimensi budaya ketekunan, dengan indikator kerajinan karyawan dalam melaksanakan tugas memperoleh nilai 3,73 dengan kriteria jawaban baik. Untuk mengatasinya, hendaknya karyawan menghilangkan gangguan yang dapat menghambat pekerjaan mereka.

Pada dimensi budaya kreativitas, dengan indikator karyawan memperlihatkan kreativitas pada pekerjaan ketika diberi peluang memperoleh nilai 3,80 dengan kriteria jawaban baik. Untuk meningkatkannya, perusahaan dapat memberikan penghargaan kepada karyawan yang kreatif. Pada indikator karyawan mengusulkan solusi kreatif untuk masalah yang dihadapi memperoleh nilai 3,66 dengan kriteria jawaban baik. Untuk meningkatkannya, hendaknya atasan berdiskusi dengan bawahannya dan meminta seluruh bawahannya untuk memberikan solusi atas masalah yang dihadapi kemudian memilih solusi yang terbaik.

Pada dimensi budaya kedislipinan, indikator ketepatan waktu karyawan dalam menyelesaikan pekerjaannya memperoleh nilai 3,78 dengan kriteria jawaban baik. Untuk meningkatkannya, atasan dapat memberikan motivasi dan pengarahan kepada karyawan sehingga dapat menyelesaikan pekerjaannya tepat pada waktunya. Pada indikator permohonan ijin karyawan untuk keperluan tertentu memperoleh nilai 3,29 dengan kriteria jawaban cukup baik. Untuk memperbaikinya, karyawan perlu meminta ijin kepada atasan dengan memberikan alasan yang logis.

Pada indikator karyawan memakai pakaian seragam yang ditentukan memperoleh nilai 3,78 dengan kriteria jawaban baik. Cara mengatasinya dengan memberikan sanksi kepada karyawan yang tidak memakai pakaian seragam sesuai dengan standar perusahaan. Pada dimensi budaya IPTEK, indikator kecepatan perkembangan IPTEK di lingkunan kerja memperoleh nilai 3,73 dengan kriteria jawaban baik. Untuk mengatasinya, dapat dilakukan dengan memperbaharui sistem aplikasi yang digunakan secara periodik.

\section{b. Komunikasi pada PT Bank Central Asia,} Tbk. Cabang Pematangsiantar

Pada dimensi komunikasi nonverbal dengan indikator gerak mata karyawan dalam menyampaikan informasi dengan nilai rata-rata 3,39 dengan kriteria jawaban cukup baik. Untuk memperbaikinya, hendaknya karyawan PT Bank Central Asia, Tbk. Cabang Pematangsiantar menggunakan gerak mata yang jelas dalam penyampaian informasi. Pada indikator tekanan suara karyawan dalam menyampaikan informasi memperoleh nilai ratarata 3,68 dengan kriteria jawaban baik. Cara mengatasinya dengan menyesuaikan tekanan suara dalam menyampaikan informasi.

Pada dimensi komunikasi verbal dengan indikator kesediaan karyawan memberikan penjelasan kepada karyawan lain yang mengalami kesulitan secara tulisan memperoleh nilai rata-rata 3,76 dengan kriteria jawaban baik. Cara mengatasinya dengan menulis penjelasan pada buku khusus sehingga dapat digunakan pada masa mendatang. Pada indikator kesediaan karyawan mendengar informasi yang diberikan secara lisan memperoleh nilai rata-rata 3,80 dengan kriteria jawaban baik. Untuk meningkatkannya dapat dilakukan dengan cara menyampaikan informasi secara menarik, singkat, padat dan jelas.

\section{c. Kinerja Karyawan pada PT Bank Central Asia, Tbk. Cabang Pematangsiantar}

Pada dimensi kemampuan komunikasi dengan indikator kemampuan karyawan dalam 
berbahasa asing memperoleh nilai rata-rata 3,02 dengan kriteria jawaban cukup baik. Untuk meningkatkannya dapat dilakukan dengan memberikan pelatihan bahasa asing khususnya bahasa Inggris kepada karyawan. Pada dimensi kerjasama dengan indikator kemampuan karyawan bekerjasama dengan atasan memperoleh nilai rata-rata 3,73 dengan kriteria jawaban baik. Cara mengatasinya, atasan dan karyawan harus menjaga hubungan yang baik serta atasan juga harus mampu untuk memotivasi dan merangkul karyawan.

Pada dimensi kemauan untuk berkembang dengan indikator kemauan karyawan menerima saran dari atasan memperoleh nilai rata-rata 3,73 dengan kriteria jawaban baik. Untuk meningkatkannya, atasan dapat memberikan kesempatan kepada bawahannya untuk melakukan feedback secara berkala. Pada indikator kemauan motivasi diri dalam bekerja memperoleh nilai rata-rata 3,59 dengan kriteria jawaban baik. Untuk meningkatkannya dapat dilakukan memberikan kesempatan promosi jabatan sehingga karyawan lebih termotivasi lagi dalam bekerja.

Pada dimensi pengetahuan produk dengan indikator karyawan mampu menyampaikan informasi produk dengan tepat memperoleh nilai rata-rata 3,66 dengan kriteria jawaban baik. Untuk meningkatkannya dapat dilakukan dengan melaksanakan uji kompetensi tentang informasi produk. Selanjutnya pada dimensi kemandirian dengan indikator karyawan mampu memberikan solusi kepada nasabah memperoleh nilai rata-rata 3,73 dengan kriteria jawaban baik. Cara mengatasinya dengan memberikan pelatihan kepada karyawan mengenai cara memberi solusi yang tepat untuk nasabah.

\section{KESIMPULAN DAN SARAN}

\section{Kesimpulan}

a. Hasil analisis deskriptif kualitatif tentang budaya organisasi berdasarkan dimensi budaya kejujuran, budaya ketekunan, budaya kreativitas, budaya kedisiplinan, dan budaya IPTEK memiliki nilai rata-rata keseluruhan 3,82 dengan kriteria jawaban baik. Dari rata-rata tersebut diperoleh nilai tertinggi sebesar 4,05 pada dimensi budaya IPTEK dengan indikator penguasaan IPTEK oleh karyawan, sedangkan nilai terendah sebesar 3,29 pada dimensi budaya kedisiplinan dengan indikator permohonan ijin karyawan untuk keperluan tertentu.

b. Hasil analisis deskriptif kualitatif tentang komunikasi berdasarkan dimensi komunikasi nonverbal dan komunikasi verbal mendapat nilai rata-rata 3,82 dengan kriteria jawaban baik. Kemudian nilai rata-rata tertinggi sebesar 4,05 dengan kriteria jawaban baik pada dimensi komunikasi nonverbal dengan gerak tubuh karyawan dalam menyampaikan informasi. Sedangkan nilai rata-rata terendah sebesar 3,39 dengan kriteria jawaban cukup baik pada dimensi komunikasi nonverbal dengan indikator gerak mata karyawan dalam menyampaikan informasi.

c. Hasil analisis deskriptif kualitatif tentang kinerja karyawan, dari dimensi kemampuan komunikasi, kerjasama, kemauan untuk berkembang, pengetahuan produk, kemandirian memperoleh nilai rata-rata 3,75 dengan kriteria jawaban baik. Dengan nilai tertinggi didapat pada dimensi kemampuan komunikasi dengan indikator kemampuan karyawan dalam berbahasa yang sopan dengan nilai 4,20. Nilai terendah terdapat pada dimensi kemampuan komunikasi dengan indikator kemampuan karyawan dalam berbahasa asing dengan nilai 3,02.

d. Hasil analisis regresi linier berganda adalah $\hat{Y}=10,054+0,357 X_{1}+0,514 X_{2}$, artinya terdapat pengaruh yang positif antara variabel budaya organisasi $\left(X_{1}\right)$ dan komunikasi $\left(X_{2}\right)$ terhadap kinerja karyawan (Y) pada PT Bank Central Asia, Tbk. Cabang Pematangsiantar.

e. Hasil koefisien korelasi pada tabel di atas diperoleh nilai $r=0,728$ yang artinya terdapat hubungan yang kuat dan positif antara budaya organisasi dan komunikasi kerja terhadap kinerja karyawan pada PT Bank Central Asia, Tbk. Cabang Pematangsiantar, sesuai dengan kriteria korelasi pada tabel. Kemudian diperoleh nilai koefisien determinasi $R=0,530$, artinya tinggi rendahnya kinerja karyawan dapat dijelaskan sebesar $53 \%$ oleh budaya organisasi dan komunikasi selebihnya $47 \%$ dijelaskan oleh faktor lain yang tidak dijelaskan dalam penelitian ini.

f. Hasil pengujian hipotesis secara simultan $($ Uji $F)$, nilai $F_{\text {hitung }}$ sebesar 21,393 $>F_{\text {tabel }}$ dengan (5\%, 2 VS 38) sebesar 3,24 atau dengan taraf signifikansinya $0,000<\alpha 0,05$ maka $\mathrm{H}_{0}$ ditolak, artinya budaya organisasi dan komunikasi berpengaruh positif dan signifikan terhadap kinerja karyawan PT Bank Central Asia, Tbk. Cabang Pematangsiantar.

g. Hasil pengujian hipotesis secara parsial (Uji t), nilai $t_{\text {hitung }}$ budaya organisasi sebesar $2,418>t_{\text {tabel }}$ dengan $d f=n-k-1 \quad(41-2-1=38)$ sebesar 2,02439 atau dengan taraf signifikan $0,020<\alpha 0,05$, maka $H_{0}$ ditolak, artinya budaya organisasi berpengaruh positif dan signifikan terhadap kinerja karyawan pada PT Bank Central Asia, Tbk. Cabang Pematangsiantar, sedangkan nilai $t_{\text {hitung }}$ komunikasi kerja sebesar $2,084>t_{\text {tabel }}$ dengan $\mathrm{df}=\mathrm{n}-\mathrm{k}-1 \quad(41-2-1=38)$ sebesar 2,02439 atau dengan taraf signifikansi 0,044 $<\alpha 0,05$ maka $\mathrm{H}_{0}$ ditolak, artinya komunikasi berpengaruh positif dan signifikan terhadap 
kinerja karyawan pada PT Bank Central Asia, Tbk. Cabang Pematangsiantar.

\section{Saran}

a. Agar budaya organisasi PT Bank Central Asia, Tbk. Cabang Pematangsiantar dapat terlaksana dengan efektif, karyawan diharapkan lebih disiplin dalam menjalankan tugasnya sesuai dengan aturan norma yang ditetapkan dalam perusahaan serta konsisten dengan budaya kejujuran, budaya ketekunan, budaya kreativitas, dan budaya IPTEK mereka dalam menjalankan tugas dan tanggungjawabnya.

b. Dalam berkomunikasi, hendaknya karyawan lebih memperhatikan gerak mata mereka dan memberikan gerak mata yang jelas agar tidak terjadi kesalahpahaman dalam penyampaian informasi.

c. Untuk meningkatkan kinerja karyawan pada PT Bank Central Asia, Tbk. Cabang Pematangsiantar, perusahaan perlu memberikan pelatihan bahasa asing kepada karyawan, menambah pemahaman karyawan mengenai pekerjaannya, meningkatkan kepekaan terhadap lingkungan sekitar sehingga dapat mengambil inisiatif dalam bekerja.

\section{E. DAFTAR PUSTAKA}

Bangun, Wilson. 2012. Manajemen Sumber Daya Manusia. Jakarta: Erlangga.
Boone, E Louis dan David L. Kurtz. 2002. Pengantar Bisnis. Jilid 1. Jakarta: Erlangga

Dessler, Gary. 2003. Manajemen Sumber Daya Manusia. Jilid 1, Edisi Kesepuluh. Jakarta: PT Indeks.

Dewi, Sutrisna. 2007. Komunikasi Bisnis. Edisi Kesatu. Yogyakarta: Andi.

Kreitner, Robert dan Angelo Kinicki. 2014. Perilaku Organisasi. Jilid 1, Edisi Kesembilan. Jakarta: Salemba Empat.

Mathis, Robert L dan John H. Jackson. 2006. Human Resouce Management. Edisi Kesepuluh. Jakarta: Penerbit Salemba Empat.

Mondy, R Wayne. 2008. Manajemen Sumber Daya Manusia. Jilid 1, Edisi Kesepuluh. Jakarta: Erlangga.

PT Bank Central Asia, Tbk. Form Penilaian Karyawan BCA tahun 2005-2016.

Purwanto, Djoko. 2006. Komunikasi Bisnis. Edisi Ketiga. Jakarta: Erlangga.

Robbins, Stephen P. 2006. Perilaku Organisasi. Edisi Kesepuluh. Jakarta: PT Indeks.

Sutrisno, Edy. 2010. Budaya Organisasi. Jakarta: Kencana Prenada Media Group.

Zainal, Veithzal Rivai., dkk. 2015. Manajemen Sumber Daya Manusia Untuk Perusahaan: Dari Teori ke Praktek. Edisi Ketiga. Jakarta: Rajawali Pers. 